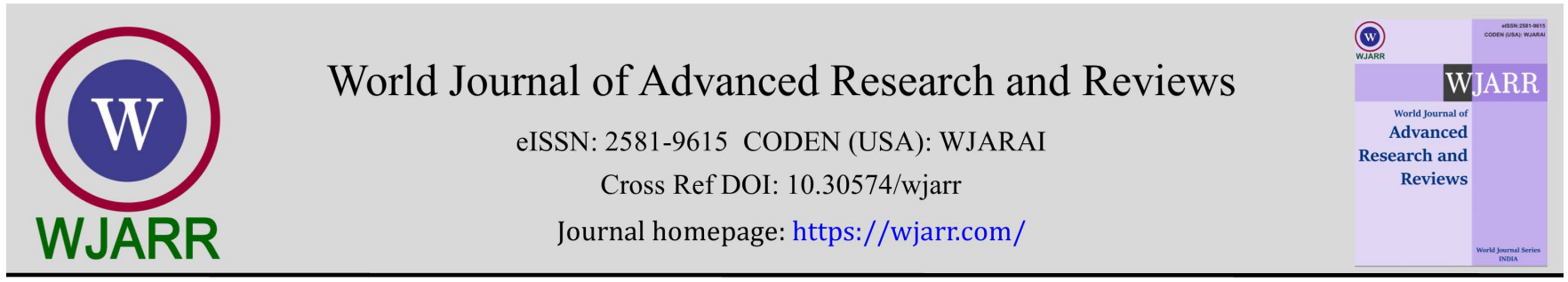

(RESEARCh ARTICLE)

\title{
Impact of calcification on potato yield
}

\author{
Midhat Glavić * and Amir Zenunović \\ Faculty of Technology, Department for Agriculture, University of Tuzla, Bosnia and Herzegovina.
}

World Journal of Advanced Research and Reviews, 2021, 12(02), 185-189

Publication history: Received on 26 September 2021; revised on 06 November 2021; accepted on 08 November 2021

Article DOI: https://doi.org/10.30574/wjarr.2021.12.2.0561

\begin{abstract}
By seed surfaces according to the information the Federal Bureau of Statistics and the Institute of Statistics Republic of Srpska of the total area under vegetables potatoes occupies $57 \%$ sowing area, so that after the corn and wheat, potatoes the most important agricultural plant in Bosnia and Herzegovina.

Most are lighter types of land - permeable, loose, sandy-humus and sandy-clay ground with crumb structure, rich in mineral and organic matter, with favorable water - air characteristics. Does not match his tough swampy lands with a high level of underground water. Tolerate acid soil reaction, and the optimum pH is 5,4-6,5.

Given that the area of Tuzla canton mainly acid soil with pH values from 4.5 to 5.5 made the production of a sample on the plot that had a pH value of 4.6 as a material for the reparation of land or quality of calcification was Fertdolomit in order to increase in $\mathrm{pH}$, after you apply Fertdolomit analysis has found that the increased pH value to 5.8.

Calcification is a measure of repair of chemical properties of soil, primarily reducing its acidity, ie. bringing the $\mathrm{pH}$ value to the optimum level for the cultivation of certain plant species calcium use of fertilizers. At the same time, this measure of the repair water-air, mechanical, physical and biological properties of soil.

Reflected in the potatoes plant in four different variants: the control, with the use of $40 \mathrm{t} / \mathrm{ha}$ of manure, the use of $40 \mathrm{t}$ / ha manure and NPK 7:20:30 $400 \mathrm{~kg} /$ ha and the use of manure $40 \mathrm{t} / \mathrm{ha}$, NPK 7:20:30 in the amount of $400 \mathrm{~kg} / \mathrm{ha}$ with supplements Fertdolomit in the amount of $3 \mathrm{t} /$ ha.
\end{abstract}

The results reflected a big point to the importance of calcification in the production of potatoes.

Keywords: Potatoes; Manure; Fertilizer; Calcification; Yield

\section{Introduction}

Potatoes are the fourth largest crop in the world today, after wheat, corn and rice in terms of total production. It is produced worldwide on an area of 19 million hectares, and the average yield of tubers is $16.5 \mathrm{t} / \mathrm{ha}$ [1].

Of the total world production of potatoes, $52 \%$ is spent on human consumption, $21 \%$ on livestock, $10 \%$ on seeds, $12 \%$ on processing, and the rest are losses. World production has increased especially in underdeveloped countries due to high productivity of nutritional production, per unit area (ha), which is about 3 times higher than that given by cereals, while in the developed world the consumption of fresh potatoes is declining and the consumption of processed products is growing (chips, flour, starch, alcohol) [2].

\footnotetext{
* Corresponding author: Midhat Glavić

Faculty of Technology, Department for Agriculture, University of Tuzla, Bosnia and Herzegovina.

Copyright $(2021$ Author(s) retain the copyright of this article. This article is published under the terms of the Creative Commons Attribution Liscense 4.0.
} 
In order to systematically implement the fertilization strategy and achieve optimal tuber quality, it is first necessary to organize and systematically control the fertility of the soil for production areas where it is planned to grow potatoes. Based on soil analysis and other available information, the required quantities and forms of fertilizers should be determined. It is also necessary to establish, in accordance with the technical and technological possibilities, the manner, quantity and time of its application.

Special attention should be given to the use of organic fertilizers and the quantities in the application, time and method of application. Particular attention should be paid to the assessment of the maturity of organic fertilizers. Also, in the definition and application of calcification materials, the application should be based on a professionally based recommendation, which must determine, in addition to the quantity, the most favorable time and method of application (Poljak M.,[3].

Land, as well as fertilization over the land, is not always sufficient to meet the needs of the crop. Eating disorders in potatoes occur on overgrown and overgrown lands. At pH 5 or lower, potatoes become less accessible to calcium (Ca), magnesium (Mg) and phosphorus (P), and an excess of ammonia (NH4), manganese (Mn) and aluminum (Al) can lead to phytotoxicity. In soils with a $\mathrm{pH}$ of 7.5 and higher, symptoms of boron (B), copper (Cu), manganese (Mn) and zinc (Zn) deficiency occur, and phosphorus becomes less accessible because it binds to calcium phosphate [4].

Secondary macronutrients $\mathrm{Ca}$ and $\mathrm{Mg}$, and micronutrients $\mathrm{Mn}, \mathrm{B}, \mathrm{Fe}, \mathrm{Cu}$, and $\mathrm{Zn}$ affect the activation of many enzymes involved in biochemical photosynthesis reactions [5].

At soil pH below 4.8, potatoes suffer from calcium deficiency. The seedlings germinate poorly and if they germinate, the plants remain stunted and produce many small tubers. When the soil is corrected by calcification immediately before potato cultivation, an intensified attack of common scab can occur. If the soil's magnesium supply is poor, dolomite limestones should be used during calcification. Calcium is not translocated foliarly into tubers. Calcium cannot be translocated in plant tissue and therefore the plant must receive it throughout its growth. In the absence of calcium, brown spots appear [6].

When determining the amount of lime for calcification, it is necessary to know the reaction of the soil, the adsorption complex, the mechanical composition, the content of organic matter, and the content of mobile aluminum in the soil. If we do not have such data, it is possible to take into account only some, and these are most often the pH value as well as the approximate mechanical composition [7].

Potato is a culture that responds extremely well to the application of manure, as well as to mineral fertilizers. Manure, in addition to nutrient input, has a very positive effect on improving the structure of the soil and water retention in the soil, and in the production of early potatoes it also has a positive effect on warming the soil. In our conditions, since we do not have a sufficient amount of manure in the production of potatoes, combined fertilization with manure and mineral fertilizers or fertilization with only mineral fertilizers is applied. The exact amount of fertilizers and the ratio of individual nutrients can be determined only after the analysis of the soil [8].

Calcium deficiency occurs on very acidic soils and during severe droughts, and the symptoms are twisting of the youngest mature leaves upwards and chlorosis with brown spotting, and brown coloration appears in the tubers in the conducting ring [9].

The application of agricultural lime in the amount of $2 \mathrm{t} /$ ha is reflected in the increase of yield and quality of tubers, and the degree of reaction is conditioned by varietal characteristics and environmental factors in a particular vegetation season [10].

In the case of potatoes and winter rye, which are otherwise considered to tolerate acidity relatively well, calcification is, especially in combination with organic and mineral fertilization, the realization of yield which in normal market conditions allows achieving a more favorable economic result [11].

In the long run, without maintaining soil fertility with the application of appropriate amounts of lime materials, and organic and mineral fertilizers, growing crops on very acidic and acidic soils can hardly be profitable, so, in this sense, the implementation of calcification is a procedure to be carried out in accordance with the rules of the profession [12].

The average number of tubers significantly depends on the number of primary shoots that are formed per one potato house, which affects the average production of tubers per plant and the total yield per unit area. The total number of 
tubers increases when planting larger fractions ( 45 - 55 and more than $55 \mathrm{~mm}$ ), and by planting them at a larger row spacing, a larger number of large tubers is formed.

[13] [14]. State that in order to achieve high and stable yields, the best varieties are those with about 10 tubers per plant. [15] Thinks similarly, stating that this number ranges between 10 and 12 tubers per plant.

The size of tubers is not only a varietal mark, but also depends primarily on the level of agrotechnical measures, the type of soil and its structure, as well as meteorological conditions during the vegetation period of potatoes [16].

\section{Material and methods}

The experiment was set up in Gornji Rainci, Kalesija municipality. Experimental plots of (10 m x $7 \mathrm{~m}$ ), with a distance between individual plots of $1 \mathrm{~m}, 16$ experimental plots (four repetitions).

The experiment includes 4 variants of fertilization:

- No fertilizer

- 40 tons / ha of manure (beef, mature)

- 40 tons of manure per ha plus $400 \mathrm{~kg}$ / ha NPK 7:20:30

- 40 tons of manure per ha plus $400 \mathrm{~kg} /$ ha NPK 7:20:30 plus Fertdolomite

Autumn plowing was performed, as well as plowed fertdolomite and manure (September), and at the end of October, NPK 7:20:30 was plowed.

In the early increase of top dressing from $150 \mathrm{~kg} /$ ha KAN $27 \%$.

Desiree variety, planted at a distance of $60 \mathrm{~cm} \mathrm{X} 25 \mathrm{~cm}(66,000$ plants per hectare).

All appropriate crop protection measures against diseases and pests have been applied.

Experimental production on a plot that had a $\mathrm{pH}$ value of 4.6 and as a material for soil quality improvement or calcification, Fertdolomite was used in order to increase the $\mathrm{pH}$ value.

After application of Fertdolomite, the analysis showed that the $\mathrm{pH}$ value increased to 5.8 .

\subsection{Granulated Fertdolomite}

Granulated fertdolomite contains $24 \%$ calcium oxide ( $\mathrm{CaO}$ ) and $16 \%$ magnesium oxide (MgO) in the form of carbonates.

In addition to carbonated Fertdolomite carbonate contains:

Nitrogen (N) 3.0\%, Phosphorus (P2O5) 2.5\% and Potassium (K20) 3.0\%.

The neutralized value of Fertdolomite with the addition of basic biogenic elements (nitrogen, phosphorus, potassium) has a neutralization value of $80 \%$.

Product purpose:

- Reduces the acidity of agricultural soils

- Improves soil structure and increases biological activity

- Reduces the solubility of heavy metals (cadmium, lead, copper, zinc...) and is an environmentally desirable product

- Supplies the soil with accessible biogenic elements: calcium, magnesium, nitrogen, phosphorus, potassium. 
After chemical analysis of the soil, the dose is determined, which is usually 1-4 $t$ / ha. The application is repeated every 3 to 4 years until the optimal acidity is achieved for the grown cultures. Thereafter, $1 \mathrm{t} / \mathrm{ha}$ is used every three years, to compensate for leaching and carbonate removal and to maintain the optimal $\mathrm{pH}$ value.

\section{Results and discussion}

The results obtained by this research are in line with the results of previous research in the surrounding countries (Croatia). This type of research is very little present in Bosnia and Herzegovina and it is impossible to compare the results with such research.

Table 1 Yield results by sample plots (tons / ha)

\begin{tabular}{|c|c|c|c|c|c|}
\hline & \multicolumn{4}{|c|}{ Yield } & Average \\
\hline Control & 8.5 & 8.5 & 7.9 & 9.4 & 8.575 \\
\hline Manure & 12.9 & 12.3 & 11.9 & 14.3 & 12.850 \\
\hline $\mathrm{M}+\mathrm{NPK}$ & 23.5 & 21.5 & 23.8 & 22.2 & 22.750 \\
\hline $\mathrm{M}+\mathrm{NPK}+\mathrm{F}$ & 31.8 & 31.2 & 30.5 & 33.2 & 31.675 \\
\hline
\end{tabular}

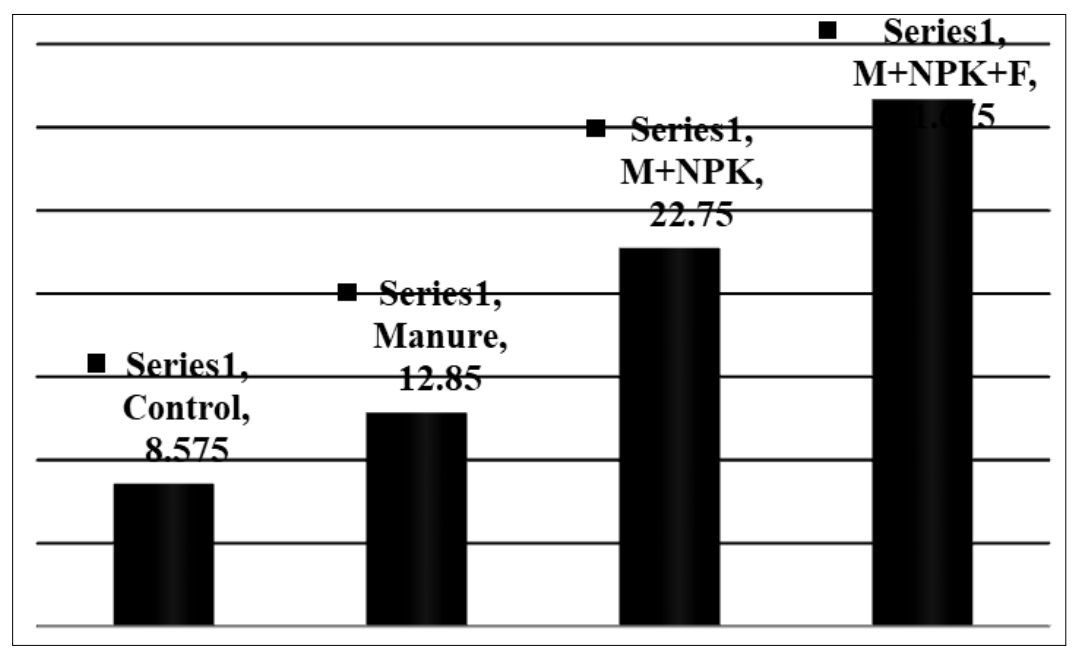

Figure 1 Average yields by experiment variants

Table 2 Difference in the yield of experimental variants

\begin{tabular}{|c|c|c|c|c|}
\hline & Average yield t / ha & $\mathbf{1}$ & $\mathbf{2}$ & $\mathbf{3}$ \\
\hline 1 & 8.5 & $\mathrm{x}$ & $\mathrm{x}$ & $\mathrm{x}$ \\
\hline 2 & 12.9 & 4.4 & $\mathrm{x}$ & $\mathrm{x}$ \\
\hline 3 & 22.8 & 14.3 & 9.7 & $\mathrm{x}$ \\
\hline 4 & 31.7 & 22.9 & 18.8 & 8,9 \\
\hline
\end{tabular}

(Labels in the table: 1 . Control, 2. Manure, 3. Manure + NPK,4. Manure + NPK + Fertdolomite)

The data that are known about the agrotechnics of potato production in this area, and that is the application of NPK and manure, given the acidity of the soil in this area indicate a very significant impact on potato yield if the soil is calcified.

The average yield with the application of fertdolomite in relation to the application of manure and NPK 7:20:30 is higher by 8.3 tons per hectare. 


\section{Conclusion}

Calcification significantly increases the yield of potatoes. Also, calcification not only increases the yield of potatoes, but also has a positive effect on the cultivation of subsequent crops in the crop rotation.

A large increase in yield compared to other variants of the experiment provides coverage of all financial costs for the implementation of calcification in the first year of production.

Calcification should be a mandatory measure to repair soil fertility as well as maintain soil fertility.

In addition to the increase in yield, the quality of potatoes is imposed, which should be the subject of other research, that is, how calcification affects the quality of potatoes.

\section{Compliance with ethical standards}

\section{Acknowledgments}

Only published papers that have been cited have been used, and are listed in the references.

\section{Disclosure of conflict of interest}

There is no conflict of interest. The results were obtained by our own experiment -Midhat Glavić and Amir Zenunović

\section{References}

[1] Vreugdenhil D, Bradshaw J, Gebhardt C, Govers F, MacKerron DKL, Taylor MA, Ross HA. Potato biology and biotechnology. Advances and perspectives. Elsevier Ltd, Amsterdam. 2008.

[2] Lešić R, Borošić J, Buturac I, Ćustić M, Poljak M, Romić D. Vegetables. Zrinski d.d., Cakovec. 2000.

[3] Poljak M. Sustainable potato growing and quality improvement. Faculty of Agriculture, Zagreb. 2006.

[4] Lešić R, Borošić J, Buturac I, Ćustić M, Poljak M, Romić D. Vegetables. Zrinski d.d., Cakovec. 2000.

[5] Marschner H. Mineral Nutrition of Higher Plants. Academic Press. London. 1986.

[6] Lešić R, Borošić J, Buturac I, Ćustić M, Poljak M, Romić D. Vegetables. Zrinski d.d., Cakovec. 2000.

[7] Mesić M. Correction of excess soil acidity on farms. Faculty of Agriculture, Zagreb. 2006.

[8] Lešić R, Borošić J, Buturac I, Ćustić M, Poljak M, Romić D. Vegetables. Zrinski d.d., Cakovec. 2000

[9] Lešić R, Borošić J, Buturac I, Ćustić M, Poljak M, Romić D. Vegetables. Zrinski d.d., Cakovec. 2000

[10] Poljak M. Sustainable potato growing and quality improvement. Faculty of Agriculture, Zagreb. 2006.

[11] Mesić M. Correction of excess soil acidity on farms. Faculty of Agriculture, Zagreb. 2006.

[12] Mesić M. Correction of excess soil acidity on farms. Faculty of Agriculture, Zagreb. 2006.

[13] Broćić ZN, Momirović Biljana Barčik, R Đekić, Examination of cultivation technology and productivity of early potato cultivars. Arhiv za poljoprivredne nauke. 2000; 61: 215 (vanr. Sv.): 131-141

[14] Bugarčić Ž, Rose Aboth Bugarčić, Đekić R, Jelena Ivan. Yield testing of Dutch potato cultivars in different agroecological conditions in Serbia. Archives of Agricultural Sciences. 2000; 61: 215 (ext. Vol.), 143-150

[15] Maksimović P. Potato production, Belgrade. 1996

[16] Ilin Ž, Đurovka M, Marković V. The importance of irrigation in potato production, Proceedings of the Institute of Field and Vegetable Crops. 1992; 20: 575-581. 